\title{
Variation in Avian Visits on Two Host Plants of the Mistletoe Tapinanthus sesselifolius Depended on Habitat Type and Presence of Matured Flowers
}

\author{
Adams A. Chaskda ${ }^{1 *} \quad$ Evelyn E. Isumafen $^{2} \quad$ Filibus D. Dami $^{1} \quad$ Longtong G. Turshak $^{3}$ \\ 1.A.P. Leventis Ornithological Research Institute, Department of Zoology, University of Jos. P.O. Box 13404, \\ Laminga, Jos-east LGA, Plateau State, Nigeria \\ 2.Departmen of Zoology, University of Jos. P.M.B. 2084, Jos, Plateau State, Nigeria
}

\begin{abstract}
This study investigated avian foraging behaviour on the Mistletoe, Tapinanthus sesselifolius with a view to determine whether avian visits to the stem parasitic plant significantly differ between its two common host plant species in the Amurum Forest Reserve, Nigeria namely; Dichrostachys cinerea and Ochna afzelii. Also the study determined whether habitat type and abundnace of the three flower developmental stages of T. sesselifolius (i.e.closed unripe, closed ripe and open flowers) influenced avian visits to T. sesselifolius. Data was obtained using focal observations; 22 individuals of each of the two plant species hosting the Mistletoe T. sesselifolius were selected through stratified sampling. Focal observations to determine avian visits were conducted over a period of 1-hour per individual plant. Flower developmental stages were sampled through direct counts on three randomly selected branches of the parasitic plant. A significant difference was observed in avian visits to $T$. sesselifolius on the two study host plants with higher mean visits per hour to $T$. sesselifolius on $D$. Cinerea. While $T$. sesselifolius around the gallery forest habitat received significantly more avian visitors than those located in the savannah scrub and rocky outcrop. Also closed ripe flowers had significant effect on avian visits with avian visits increasing significantly to $T$. sesselifolius having higher numbers of closed ripe flowers. The complex structure of $D$. cinerea and the dense vegetation structure of the gallery forest could act as buffer against birds of prey and may have encouraged more visits to T. sesselifolius based on these factors. Also, the tamper proof nature of ripe flowers and its high nectar content as observed in previous studies is speculated as reasons for its significant positive effect on avian visits in the study. These observations may have implications on the reproductive potential of the stem parasitic plant since reduced pollinator visits is known to limit pollen deposition and eventual fruit set in plants.
\end{abstract}

Keywords: avian visits, Tapinanthus sesselifolius, host plant, habitat type

DOI: $10.7176 / \mathrm{JNSR} / 12-8-01$

Publication date: April $30^{\text {th }} 2021$

\section{Introduction}

The fitness of ornithophilous (i.e. bird pollinated) plants, is established to increase with avian visits and duration of foraging this is because this variables increases chances of pollen deposition at stigma of flowers and consequently enhanced seed/fruit set (Klinkhamer and De Jong, 1990; Ågren, 1996; Ladley et al., 1997; Kwak et al., 1998; Bosch \& Waser, 1999; Ashmann et al., 2004).

Among several plant flowers visited and pollinated by birds, are those of the xylem-parasitic Mistletoe family, Loranthaceae (Barlow, 1983; Ladley et al.1997; Norton et al., 1997). Mistletoes grow on the branches of several host trees and shrubs which includes Parkia biglobosa, Acacia seyel (Mimosoideae), Anogeissus leiocarpus (Combretaceae) (Barlow, 1983; Boussim et al., 2004) absorbing water, water-conducted nutrients and organic solutes from the host s xylem but photosynthesise on its own using its leaves (Ladley and Kelly, 1996; Vaknin et al., 1996). Most of the plants possess obligate explosive flowers where only ripe flowers (often with dark terminal bud) open up upon tweaking by birds or strong mandibled insects (Ladley et al., 1997; Watson, 2001). During this process, pollen accumulated on the fore-crown of birds can get to a flower s stigma when it makes contact with the bird s head during foraging for nectar (Ladley and Kelly, 1995).

The effect of floral characteristics such as nectar quantity and quality as well as floral density and size in regulating avian visitors have been previously widely considered (Klinkhamer and de Jong 1990; Ladley et al., 1997; Johnson et al., 2006; Chaskda et al. 2013). However, in the case of the African endemic Loranthaceae Mistletoes, specifically the species Tapinanthus sessilifolius previous studies have not fully exploited the above aspects particularly how avian visits relates with the various host plant species of the parasitic plant and the habitat types in which individuals are located. This is important considering that pollinator birds have been shown to adjust foraging behaviour in favour of such patches that gives maximum energetic reward with negative implications in terms of reduced fitness for the avoided plant (Gill and Wolf 1975). Therefore, this study aims at determining whether avian visit rates to $T$. sesselifolius differed between its two dorminant host plant species Dicrostachys cinerea and Ochnia afzelii based on a previous survey in the Amurum Forest Reserve 
and whether such differences if any depends on the habitat type in which the host plant is located and the abundance of the different flower developmental stages on the plant (Chaskda et al., 2013).

\section{Materials and methods}

\subsection{Study area}

This Research was carried out within the Amurum Forest Reserve $\left(9^{0} 53 \quad \mathrm{~N}, 8^{0} 59\right.$ E) located $15 \mathrm{~km}$, northeast of Jos, Plateau State, North-Central Nigeria. The area spans 300 ha and is characterized by various habitat types which include patches of gallery forest, scrub savannah rocky out crops and grassland (Ezealor, 2002) (Fig. 1). These habitat types host several plant species some of which are hosts to the parasitic mistletoes, such as $T$. sesselifolius, T. dondrofolius and few others (Chaskda, 2005). The forest has been identified as an Important Bird Area (Ezealor, 2002) and hosts a number of nectar feeding birds such as the scarlet-chested sunbird (Chalcomitra senegalensis) and the Green-headed sunbird (Cyanomitra verticalis). These characteristics of the Amurum forest Reserve influenced its choice as a study area.

\subsection{Data collection}

Data collection was conducted during the wet season of 2012 starting from first week of August to the last week of September. Two of the top five plant species earlier reported as major hosts of the mistletoes T. sessilifolius (Chaskda, 2005) that is D. cinerea and O. afzelii were chosen for this study. Their choice was also based on their distribution within the reserve. 22 parasitized individuals of each host plant species where observed using Focal Observation Technique ( $c f$. Ladley et al., 1997). None of the selected candidate study plant species were less than $1.0 \mathrm{~m}$ in height and were selected using stratified random sampling such that no two individuals were less than $30 \mathrm{~m}$ from each other to achieve wider spread of sampling points across the reserve. The 22 individual plants selected for the two host plant species were observed each for a period of one hour using a binocular (Trekka, $10 \times 45$ field of view) at the rate of minimum of three individual plants per day. Observations were conducted at a minimum distance of $10 \mathrm{~m}$ away from focal plant to avoid distracting avian behaviours. All observations were conducted between $0630 \mathrm{hrs}$ to $1130 \mathrm{hrs}$. During the observations, the following variables were recorded:

i. $\quad$ Frequency of visits by each bird species visiting $T$. sessilifolius on the study host plants.

ii. The particular T. sesselifolius host plant species being sampled.

iii. The habitat type where each individual of the study host plant species was located.

iv. Mean number of the various flower developmental stages of T. sesselifolius per branch namely; closedunripe (early flower developmental stage characterised by pink to yellow terminal bud), closed ripe (has dark-brown terminal bud and has matured stigma and pollen ready for pollination) and open flowers (often opened by the activity of birds and strong mandibled insects that have probed for nectar) (Ladley et al., 1997; Watson, 2001; Chaskda et al., 2013). Each flower type was sampled on three branches of the parasitic plant and averages taken.

Individuals belonging to each bird species were not distinguished throughout the study because not all birds in the area were ringed or colour banded. Thus, comparisons between birds were based on species differences.

\subsection{Data analysis}

Data was analysed using the SPSS Statistical package, version 17.0 (www.spss.com). The Independent sample ttest was used to test the significance of the differences in mean number of visits between the bird species recorded on $T$. sesselifolius during the study. Using number of avian visits as dependent variable, the General Linear Model (GLM) was used to determine the significant predictors of avian visits to T. sesselifolius the backward deletion technique of the most non-significant predictors was used until the minimum model containing significant predictors of avian visits was achieved. Predictors tested include: host plant species, habitat type, number of unripe flowers, number of ripe flowers, number of open flowers and the interactions between host plants and the different flower developmental stages.

\section{Results}

\subsection{Avian visitors to T. Sesselifolius}

Two bird species; the variable sunbird, Cinnyris venustus and the scarlet-chested sunbird, Chalcomitra senegalensis were recorded foraging on $T$. sesselifolius during the study. Variable sunbird had a total of 80 visits (representing $62.5 \%$ of 128 visits) while scarlet-chested sunbird had 48 visits $(37.5 \%)$; the visits by the two bird species differed significantly (Independent Sample t-test, $\mathrm{t}=2.787, \mathrm{P}=0.007$ ); variable sunbird had 40 visits $(45.46 \%)$ to $T$. sesselifolius on $D$. cinerea and all the 40 visits to $O$. afzelii $(100 \%)$ while the scarlet-chested sunbird had 48 visits $(54.55 \%)$ to the parasitic plant on $D$. cinerea and none to $O$. afzelii $(0 \%)$. 


\subsection{Differences in avian visits across host plants, habitat type and flower abundance}

Avian visits to $T$. sesselifolius, differed significantly between the two host plants $D$. cinerea and $O$. afzelii (Table 1, Fig. 2). Also, avian visits to T. sesselifolius on the two host plant species depended significantly on the habitat type in which the individual host plant was located. For example the highest mean visits to T. sesselifolius on both $D$. cinerea and $O$. afzelii occurred in the gallery forest as compared to the other habitat types (Table 1, Fig. 2). Also, mean avian visits related positively with the number of ripe flowers on T. sesselifolius (Table 1, Fig. 3) irrespective of the host plant species on which the parasitic plant is growing (GLM, $\mathrm{F}_{1,166}=3.274, \mathrm{P}=0.072$ ).

Table 1. Significant predictors of avian visits to T. sesselifolius

Dependent model: number of avian visits per hour

\begin{tabular}{|l|l|l|l|}
\hline Variable & df & F & P \\
\hline Host plant species & 1,171 & 139.72 & $<0.001$ \\
\hline Habitat type & 2,171 & 14.82 & $<0.001$ \\
\hline Number of mature ripe flowers per branch & 1,171 & 10.49 & 0.001 \\
\hline
\end{tabular}

*all significant values are at 0.05 level

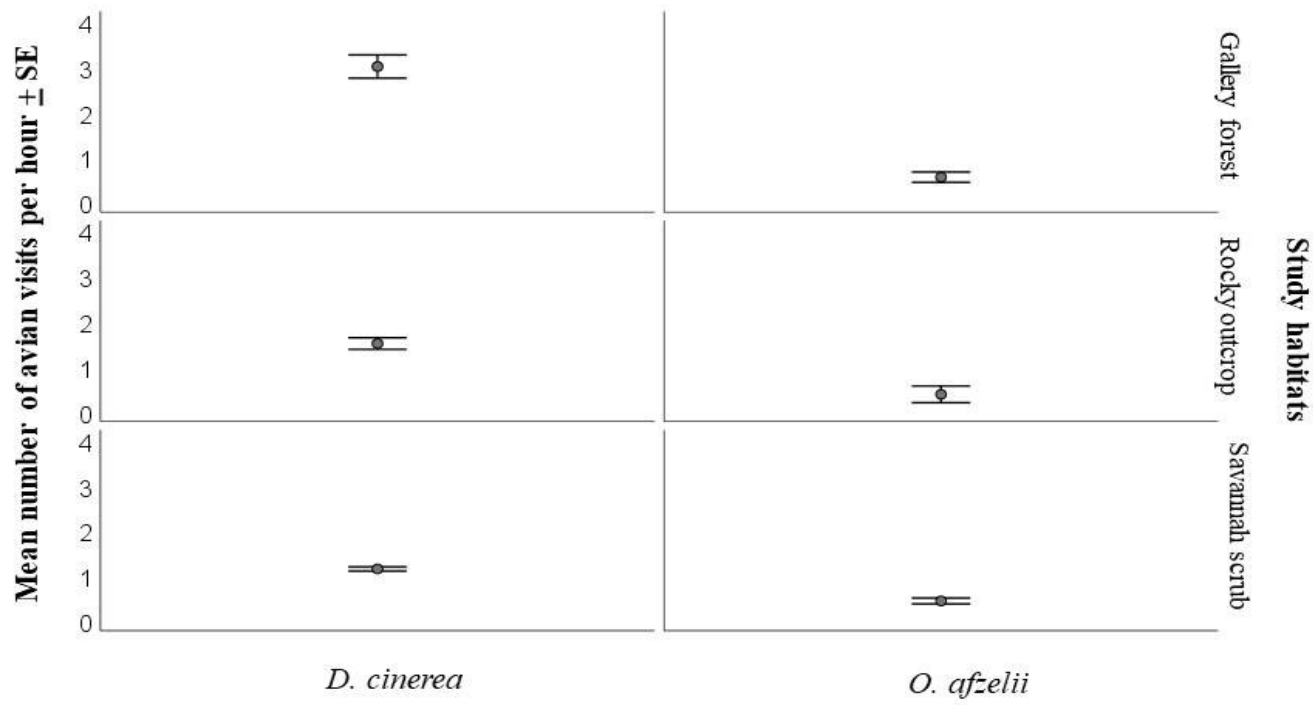

T. Sesselifolius host plant species

Figure 2. Avian visit rate between study host plant species and habitat type in the Amurum Forest Reserve

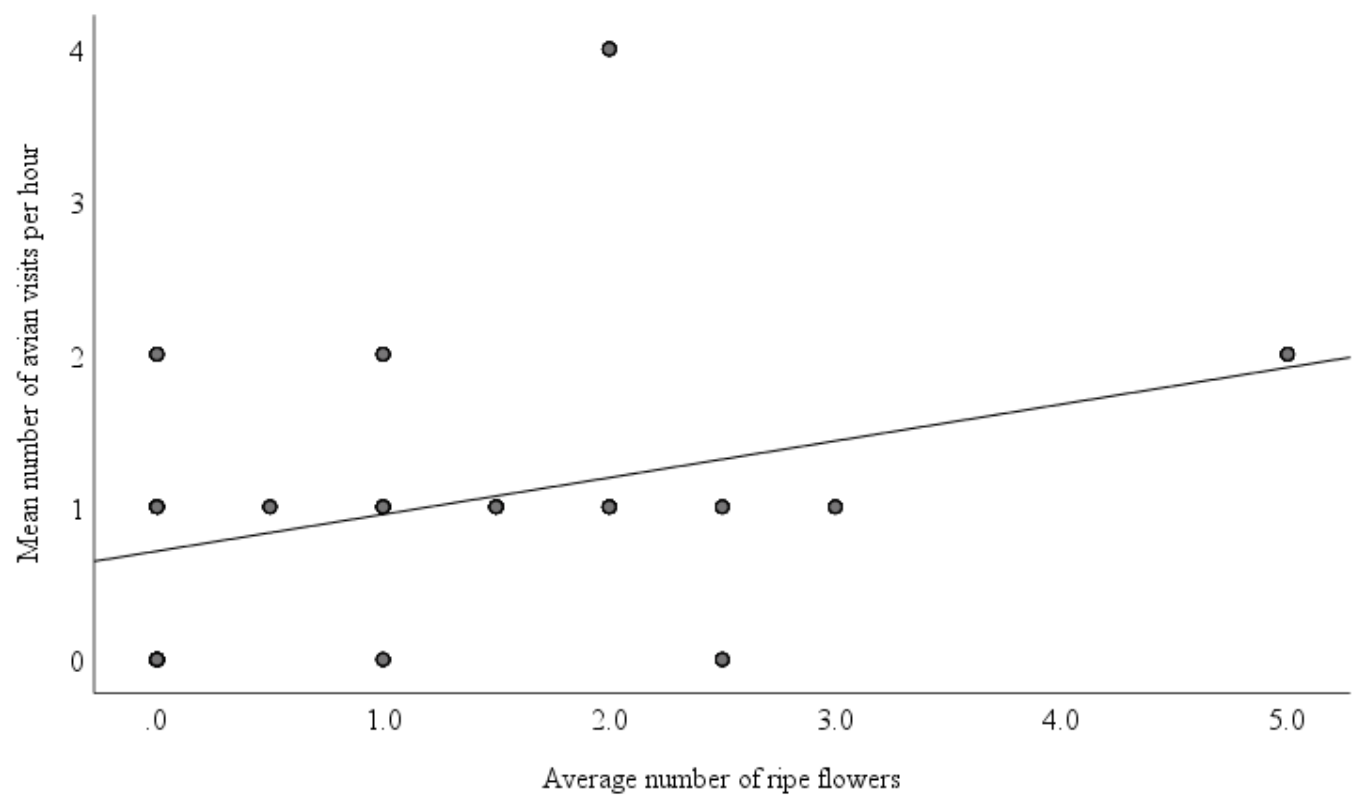

Figure 3. Avian visit rate per hour and average number of ripe flowers 


\section{Discussion}

The results of these study showed that the variable sunbird and the scarlet-chested sunbird are avian pollinatos of the mistletoe T. sesselifolius in the Amurum Forest Reserve. However, the variable sunbird seems to be more versatile as it appears to be the dominant forager on the two host plant species of the parasitic plant with the scarlet-chested sunbird never recorded throughout the study on $O$. afzelii.

Higher visits by avian visitors to $T$. sesselifolius on the host plant $D$. cinerea can be attributed to several factors. Among these is the nature of the host plant $D$. cinerea which poses complex structure comprising of thorns, which looked obstructive with the potential of reducing foraging efficiency of predatory birds as speculated in previous studies (Chaskda, 2005) thus, if pollinator birds recognize this protective effect, it may influence their preference to forage on the host plant. However, nectar quantity and quality have also been previously reported to have positive effects on avian visits (Ladley et al., 1997). Other plant features known to have effects on avian visits include plant size, floral size and density of flowers on a plant (Klinkhamer and de Jong, 1990; Ladley et.al., 1997; Ashmann et.al., 2004).

Similarly, more visits to $T$. sesselifolius in the gallery forest habitat as against other habitat types considered in this study, could still be tied to the predator hypothesis as the gallery forest has more dense vegetation that could provide cover against predators compared to the more open savannah scrub with scattered shrubs and degraded areas or the more open rocky outcrop with rocky surfaces limiting efficient plant growth.

On the other hand, effects of closed ripe flowers on avian visits may not be unconnected with its nectar content. Such flowers have been demonstrated in the past to have high nectar quantity and their sealed nature is suspected to provide an assuring reward for foraging birds. These are likely to be energetically more rewarding than re-visiting already opened flowers or the closed unripe flowers that do not contain nectar (Ladley et al. 1997). As a result, larger sunbirds feed mainly on unopened buds (Gill and Wolf 1975).

Thus, the pattern of foraging behaviour by avian visitors as observed in this study may have huge implications on the reproductive potential of $T$. sesselifolius. This is because increased avian visits and duration of foraging is known to have high implications on the pollination potential of a plant; the higher the visits and duration of foraging, the higher the tendency of flowers getting pollinated and consequently, the higher the fruit set on the plant (Ågren, 1996; Roll et al., 1997; Kwak et al., 1998). Thus, observations from this study may have reproductive implications for $T$. sesselifolius depending on the host plant species, habitat type and abundance of matured flowers on the plant.

\section{References}

Ågren, J. (1996). Population size, pollination limitation, and seed set in the self-incompatible herb Lythrum salicaria. Ecology 77: 1779-1790.

Ashman, T., Knight, T.M., Steets, J.A., Amarasekare, P., Burd, M., Campbell, D.R., Dudash, M.R., Johnston, M.O., Mazer, S.J., Mitchell, R.J., Morgan, M.T. \& Wilson, W.G. (2004). Pollen limitation of plant reproduction: ecological and evolutionary causes and consequences. Ecology 85 (9): 2408-2421.

Barlow, B. . (1983). Biogeography of Lorantaceae and Viscaceae. Australian Academic, 348

Bosch, M. and Waser, N.M. (1999). Effects of local density on pollination and reproduction in Delphinium nuttallianum and Aconitum columbianum (Ranunculaceae). American Journal of Botany 86: 871-879.

Boussim, I.J., Guinko, S., Turquet, C. \& Sallé, G. (2004). Mistletoes of the agroforestry parklands of burkina faso. Agroforestry Systems 60: 39-49.

Chaskda, A. A. (2005). Implications of avian foraging on the reproductive ecology of the mistletoe, Tapinanthus globiferus (Loranthaceae). An MSc thesis in the Department of Zoology, University of Jos, Nigeria.

Chaskda, A.A., Mwansat G.S. \& Ottosson U. (2013). Implications of floral status, plant isolation and microclimatic conditions on a hemiparasitic plant-avian pollinator interaction. Journal of Natural Sciences Research, 3 (15): 26-32.

Ezealor, A.U., ed. (2002). Critical sites for biodiversity conservation in Nigeria. Nigerian Conservation Foundation: Lagos, Nigeria. Pp65

Gill, F.B. \& Wolf, L.L. (1975). Foraging strategies and energetics of east african sunbirds at mistletoe flowers. American Naturalist 109: 491-510.

Johnson, S. D., Hargreaves, A. L. \& Brown, M. (2006). Dark bitter-tasting nectar functions as a filter of flower visitors in a bird-pollinated plant. Ecology 87: 27092716.

Klinkhamer, P.G.L. \& de Jong, T.J. (1990). Effects of plant size, plant-density and sex differential nectar reward on pollinator visitation in the protandrous Eschium vulgare (Boranginaceae). Oikos 57:399-405.

Kwak, M.M., Velterop, O. \& Van Andel, J. (1998). Pollen and gene flow in fragmented habitats. Applied Vegetation Science 1: 37-54.

Ladley, J.J. \& Kelly, D. (1996). Dispersal, germination and survival of new zealand mistletoes (Loranthaceae): dependence on birds. New Zealand Journal of Ecology 20 (1): 69-79.

Ladley, J.J. Kelly, D. \& Robertson, A.W. (1997). Explosive flowering, nectar production, breeding systems and 
pollinators of new zealand mistletoes (Loranthaceae). New Zealand Journal of Botany 35: 345-360.

Norton, D.A.; Ladley, J.J. and Owen, H.J. (1997). Distribution and population structure of Loranthaceous mistletoes Alepis flavida, Peraxilla colensoi and Peraxilla tetrapetala within two new zealand nothofagus forests. New Zealand Journal of Botany 35: 323-336.

Roll, J., Mitchell, R.J., Cabin, R.J. \& Marshall, D.L. (1997). Reproduction success increases with local density of conspecifics in a desert mustard (Lesquerella fendleri). Conservation Biology, 11: 738-746.

Vaknin, Y., Tov, Y.Y. \& Eisikowitch, D. (1996). Flowering seasonality and flower characteristics of Loranthus acaciae Zucc. (Loranthaceae): implications for advertisement and bird pollination. Sexual Plant Reproduction, 9: 279-285.

Watson. D.M (2001). Mistletoes- A keystone resource in forests and wood lands, worldwide. Annual Review of Ecology and Systematics, 32: 219-250. 